\title{
To teach writing: Teachers' perspectives on how to promote children's writing development in the Swedish preschool class
}

\author{
Susanna Andersson^, Gunilla Sandberg and Anders Garpelin \\ Mälardalens University
}

\begin{abstract}
This study focuses on how teachers in Swedish preschool classes describe their work to promote children's early writing. The research questions are the following: According to teachers, in what daily activities are children given the opportunity to write? How do teachers describe their support for children's writing processes? The empirical data was collected from interviews with twelve teachers working in preschool classes in seven different Swedish municipalities. The result shows that preschool class teachers express how they work to promote both individual and group writing. It reveals two different approaches regarding guiding children to develop their writing skills. First approach puts emphasis on working to develop creative and functional writing based on the child's own interests, life experiences and level of knowledge. The second approach is primarily characterised by working on technical abilities; forming letters of the alphabet and developing the child's phonological awareness. It was also found that there are teachers who use both approaches in their teaching. Teachers utilise various support strategies to develop children's writing skills. These encompass everything from individual and group activities to the use of various artefacts in the teaching environment. The support that teachers offer children might be divided into high-level and low-level support.
\end{abstract}

Keywords: Preschool class teaching; scaffolding; teaching approaches; writing activities

Responsible editor: Oddny Judith Solheim

Received: November, 2018; Accepted: June, 2019; Published: October, 2019

\section{Introduction}

Some children recognise letters and are able to read and write before they begin primary school, while others require more support and structured teaching. The early stimulation of children's literacy and the opportunity to explore literature in a meaningful context, as well as through structured teaching, play an important role in the progress of their future literacy development (Baker, Scher \& Mackler, 1997; Barton, 2007; Swick, 2009).

*Correspondence to: Susanna Andersson, Mälardalens University, Box 883, 72123 Västerås, Sweden. Email: susanna.andersson@mdh.se

(C) 2019 S. Andersson, G. Sandberg \& A. Garpelin. This is an Open Access article distributed under the terms of the Creative Commons Attribution 4.0 International License (https://creativecommons.org/licenses/by-nc/4.0/), allowing third parties to copy and redistribute the material in any medium or format and to remix, transform, and build upon the material for any purpose, even commercially, provided the original work is properly cited and states its license. 


\section{S. Andersson, G. Sandberg $\mathcal{E}$ A. Garpelin}

The purpose of this article is to deepen knowledge of how teachers in Swedish preschool classes describe their work to promote children's early writing. The research questions are the following: According to teachers, in what daily activities are children given the opportunity to write? How do teachers describe their support for children's writing processes?

In Sweden, since 1998, there has been a bridge year between preschool and primary school referred to as 'preschool class', which is only for six-year-olds (Swedish National Agency for Education, 2001). In order to clarify the purpose and content of preschool class, and to make teaching more equivalent, curriculum texts were introduced in 2016. In the field of written language development, teaching in preschool classes should utilize the curiosity of pupils and provide them with opportunities to develop their interest in communicating verbally and in writing. The work carried out in preschool class, of laying the foundations for the pupil's future literacy, may include the discovery and use of written characters and other symbols to convey a message, drawing and writing their own books, fairy tales or to-do lists (Swedish National Agency for Education, 2016a; Swedish National Agency for Education, 2016b). The preschool class has been criticized for not making the intended transition clear enough to children, negatively impacting their reading and writing skills (Sandberg, Hellblom-Thibblin \& Garpelin (2015). According to previous research (Chomsky, 1991; Ehri \& Wilce, 1987; Hofslundsengen, Eriksen Hagtvet \& Gustafsson, 2016), it is vital to develop children's ability in writing. This article deals with that dilemma through scrutinizing writing activities for children as described by teachers.

\section{Research on writing development}

It is well-known that phonological awareness and letter recognition are important skills for learning to read and write (Hagtvet, 1997; Lundberg, Frost \& Petersen, 1988). Writing skills develop when the teacher actively participates in the child's writing process, consciously models writing and supports the child by offering various strategies and artefacts. Much of the previous research on writing development has focused primarily on technical skills, with less importance being placed on how to best guide and support children to become effective writers (Bingham, Quinn \& Gerde, 2017; Gerde, Bingham \& Pendergast, 2015; Gerde, Bingham \& Wasik, 2012).

Literacy development begins early in the child's life, even before they begin preschool and school, and continues in interaction with other people in many different contexts. It is important for teachers to understand the child's stage of development if they are to provide adequate support, as this has been shown to have a connection with the child's reading development. Many researchers contend that the child's first drawings, scribbles and invented spelling are steps towards writing. At first the child will write rows of symbols resembling letters without any understanding of the relationship between graphemes and phonemes. The child will subsequently develop an ability to narrate, draw pictures, form letters, write words and increasingly develop awareness of the communicative function of letters and words (Barton, 2007; 
Chomsky, 1991; Clay, 1991; Gerde et al., 2015; Hermansson, 2013; Hofslundsengen et al., 2016).

Hagtvet (2006) describes writing in terms of the following formula: writing $=$ encoding $\times$ conveying a message. Encoding covers writing and spelling. Conveying a message is intended meaning and is linked to the content and requires that the writer is able to express themselves so that the content is clear.

\section{Didactic approaches to writing development}

Hagtvet, Dalby, Grindheim, Lillestølen and Palsdottir (1988) believe that a six-yearold is often interested in the alphabet and language, and that this interest should be encouraged. Other studies of emergent reading emphasise that children's experiments with invented spelling are connected to how they learn to read under their own steam. The major potential of invented spelling is that it can act as motivation for children to explore written language based on their own zone of proximal development, and even function as a support for cracking the reading code (Ahmad \& Lobardino, 2000; Ehri \& Wilse, 1987; Hofslundsengen et al., 2016; Ouellette \& Sénéchal, 2008).

Studies have shown that a computer as a support for writing have a motivational effect and encourage children to write the letters of the alphabet, words and stories (Hermansson, 2013; Hultin \& Westman, 2013; Gerde, Bingham \& Wasik, 2012). On the other hand, Skantz Åberg, Lantz-Andersson and Pramling (2014) have demonstrated that the computer may hamper children's functional and creative writing, as a good deal of energy is expended in dealing with technical skills such as computer use and spelling, rather than developing the narrative content.

Studies have shown that when the teacher is active - modelling writing and providing the child with feedback on their emergent writing - the child's reading and writing will demonstrate improved development compared to those children who do not receive guidance and support. Writing skills develop in a social context in which adults model writing, use written language together with children in a meaningful context and utilise writing in the learning environment (Dennis \& Votteler, 2013; Gerde et al., 2012; Gerde, Goetsch \& Bingham, 2016; Vygotsky, 1978; Wasik \& Hindman, 2011). A study by Bingham, Quinn and Gerde (2017) investigated how teachers use different artefacts and how they didactically respond to children's emergent writing through encouragement and modelling, both individually and in a group. The results of the study demonstrate that the scaffolding employed by teachers when they model writing can be split into two levels, low-level and high-level support. The study shows that it is not common practice for teachers to model narrative construction but rather their focus is on the technical ability to form letters through writing down words.

If the technical aspect of learning to form letters is emphasised, then copying words from the whiteboard or paper may be one approach to increasing children's motivation and interest in writing. If copying is to act as scaffolding for writing, then children should be able to choose words and actively participate in the writing, as well as receive positive feedback (Eriksen Hagtvet, 1990; Vygotsky, 1978). 


\section{S. Andersson, G. Sandberg $\mathcal{E}$ A. Garpelin}

Free and creative writing stimulates the imagination and language development, which should also be encouraged to prevent children from getting caught in copying others (Eriksen Hagtvet, 1990). One method for developing a more functional and creative writing process is Writing Workshops, during which children are allowed to write from their own life experiences and are therefore more motivated to write (Behymer, 2003; Dennis \& Votteler, 2013; Jasmine \& Weiner, 2007). Studies over recent years have examined the types of written-language activities children encounter and experience in Swedish preschool classes. A great deal of emphasis is placed on developing children's phonological awareness; working with sounds, letters and the alphabetic code. This may be a result of research that has shown the importance of phonological awareness in the continued teaching of reading and writing (Fast, 2007; Sandberg, 2012; Skoog, 2012). Teachers in preschool classes also have an important role in responding, listening, seeing and interpreting those spontaneous writing activities that arise during play and lessons, so that they can guide children and develop their writing through meaningful, text-creating activities (Hermansson, 2013).

Preschool class teachers display an ambivalent attitude on how to develop emergent writing. Some teachers allow children to freely write their own books, stories and other texts from the beginning of the preschool class. Other teachers focus more on technical skills (Fast, 2007). Preschool class teachers often lack knowledge about theories of reading and writing development, as it has not been included in their education (Alatalo, Meier \& Frank, 2017).

\section{Theoretical points of departure}

The theoretical points of departure for this study are the perspectives on teaching and development offered by Vygotsky (1978) and Wood, Bruner and Ross (1976) respectively. Vygotsky emphasised that social interaction is the principal driving force behind childhood learning. Together with a more competent person the child can solve a task and complete a skill that he/she is not yet capable of on their own. Vygotsky introduced the concept of the zone of proximal development (ZPD) which is the difference between what a learner can do without help and what she or he can do with help from someone else. Central to this, and an essential task for the teacher, is the adaption of teaching to challenge the child in their own ZPD. Imitation plays an important role in language development and is part of the ZPD. According toVygotsky, imitation is not to be confused with copying but should rather be viewed as reproduction, given that it occurs within the framework of the ZPD (Vygotsky, 1978). Vygotsky also pointed out that too much mechanical copying, for example of letters and words from pre-printed teaching materials, may be counterproductive. In order to succeed in motivating the child and maintaining their interest and participation, they themselves must be able to choose what to imitate (Vygotsky, 1978). Through imitation, the child can perform at a high level with the aid of supporting individuals, something that has given rise to another concept generally associated with the ZPD - scaffolding. According to Wood, Bruner and Ross (1976), scaffolding can be described as a temporary 
support structure for a child's learning process that with time becomes unnecessary. Säljö (2010) contends that this support can take various forms; perhaps through conversation with the child, written instructions or the use of physical objects.

\section{Method}

The study is based on an interpretative approach intended to provide an in-depth understanding of how teachers work to promote and support children's early writing development (Denzin, 1996; Erickson, 1986; Eriksen Hagtvet, 1990).

\section{Data collection}

Empirical data was collected from interviews with twelve teachers working in preschool classes in seven different Swedish municipalities. Nine of the teachers working in preschool class are educated preschool teachers and three of them have a degree as primary school teachers. The teachers' experience of teaching preschool classes ranged from a single term to around twenty-five years.

Contact was initially made with school management and then with teachers working in preschool classes. In total, the researchers contacted school managements and teachers in 22 municipalities, and invitation were sent to 185 teachers.

The respondents were informed of the purpose of the study and how it was to be implemented, that their participation was voluntary and that they were at liberty to terminate their involvement at any time. The recorded sound files were pseudonymised and securely stored to prevent unauthorised access. Respondents were informed that the data would be used solely for research purposes (CODEX). Kvale and Brinkmann (2014) describe research interviews as a method for understanding the world from the interviewee's viewpoint. The semi-structured interviews were based on two general themes: The first theme in the interview dealt with the different forms of writing activities that was carried out during any given week, such as language games, reading, writing activities and working with sound and letters. The second theme in the interview dealt with instructional and learning environment, such as study books, writing material and computers that the children had access to (Forsey, 2012; Kvale \& Brinkmann, 2014). Prior to interviews, all teachers were asked to write down a weekly timetable and describe the written-language activities implemented over the week. This weekly timetable functioned as a point of departure for each interview. Interviews commenced with a question on the teacher's professional background and number of years teaching a preschool class, followed by a discussion of the weekly timetable and writing activities.

The interviews lasted between 45 and 60 minutes, were conducted at the interviewees' places of work and were recorded on an MP3 recorder. The recordings were transferred to a computer, the respondents were pseudonymised and the material transcribed. 


\section{S. Andersson, G. Sandberg $\mathcal{E}$ A. Garpelin}

Data analysis

Analysis of the interviews began during the transcription process itself and were thematically analyzed according to Braun and Clark (2006). After transcribing, a repeated reading of the interviews was initiated to get an overview of the material after which categorization was initiated following the respondents' statements. Based on the study's purpose and research questions, the teachers' answers were marked under different codes. Then a process was started by grouping and sorting the categories to identify, analyze and search for themes. "A theme captures something important about the data in relation to the research question, and represents some level of patterned response or meaning within the data set" (Braun \& Clark, 2006, p. 10). The initial analysis was done by the first author. Then a further analysis was carried out by the entire author group through discussions about how codes can be sorted under different themes and how these themes should be described.

\section{Results}

The data was organised as a whole into two themes; Writing activities and Support. It was then possible to subdivide the theme Writing activities into Children's individual writing and foint writing. Children's individual writing dealt with how the children themselves chose to write in accordance with their own interests, life experiences and levels of knowledge. foint writing primarily dealt with writing activities initiated and led by the teacher with the entire class, or when children worked together on a group writing assignment. Teachers' support strategies (how they support and guide the children's writing) occurs in both Children's individual writing and foint writing. From these themes, the researchers crystallised the contexts in which children had the opportunity to write during day-to-day teaching activities, as well as the teachers' descriptions of how they support and guide the child's individual writing. The results of this analysis are presented in the following two sections.

\section{Children's individual writing}

The analysis of the teacher descriptions of the writing activities reveal two different approaches regarding the importance of challenging, stimulating and guiding children to develop their early writing skills. The first approach places great weight on working to develop children's creative and functional writing based on the child's own interests, life experiences and level of knowledge. The second approach is primarily characterised by working with letters and developing the child's phonological awareness.

One teacher who represents the first of these approaches consciously works to develop a more creative and functional writing process using the Writing Workshop method. The teacher models how a narrative is constructed by drawing a picture and then adding words and sentences. According to the teacher, the purpose of this is to encourage children to begin writing as quickly as possible, and to help them learn to read by first writing: 
Word to picture. For every word, everything I draw, I can write something. I can write about the cupboard. The writing method is intended to get things started quickly and write about the tiniest detail. It need not be anything important. In this way I think you learn to read by writing a great deal. (LD)

Other examples show how teachers encourage children to write based on their own interests, experiences and level of knowledge; by allowing the child to write about their weekend in their Monday Book or evaluate the past week each Friday in their Calendar:

We have had a book where they write too. The Monday book we have called it. And then they write in it, maybe what they have done this weekend, and those who cannot write at all, then they must say what they want to write about, and we write before and they can write. (LJ)

Then we started with a Calendar. Every Friday we talk about the week, what we have done. Why we did it? And then they write something, yes something they remember from the week. (LL)

Some teachers are doubtful about the importance of stimulating and encouraging children's emergent writing: "No, not this year. Perhaps we will introduce it gradually. Because now they have the book, there are actually a few pages left. When we have finished the week's letter." (LH).

Another didactic strategy to develop children's writing abilities is for the teacher to encourage writing in meaningful contexts and situations. By encouraging children to draw pictures, write picture captions and use different artefacts, they are given the opportunity to explore writing based on their own life experiences and interests:

We allow them to write from the first moment. During the autumn, we visited my place on one occasion. They were then asked to write about it. We prepared a collage, we have pictures and write under them. We encourage them to write in all situations. When they've been on a school trip, about their Christmas holidays, about memories. We use the booklet to write in. We now have a bring-a-toy day. They draw the toy they've brought with them and then write about it. (LF)

The second approach that emerges from the analysis involves the teacher primarily focusing on technical abilities, such as spelling, pronunciation and phonological awareness. The analysis shows that the majority of the teachers interviewed work with the alphabet, but in different ways:

We go through the alphabet. We start with letter A. We take them in order. Then the children have a booklet, they can write the letter, draw something to the letter, big and small letter letters. Then we talk about something that starts with that letter. (LG)

We go through the alphabet from A to the end. One letter each week and there we present primarily how they sound, we want to emphasize that. Then we look at the "letter Train" a small film where they tell a story about the letter. How to write the letter and how words are written that begin with that letter. Then the children have a workbook that they work in. We do this every week. (LH)

The analysis also shows that all preschool class teachers work with language games in their teaching to develop children's phonological awareness, but that they use them 


\section{S. Andersson, G. Sandberg \& A. Garpelin}

in varying degrees. Some teachers work daily with language games, while others work less frequently: "Every day determined. The fun thing about language games is that you can do it as a game but aim to make them learn sounds and letter." (LC).

It appears from the analysis that teachers make use of both approaches regarding children's own writing, that is, they focus on technical skills and encourage children to write their own according to their interest, experience and level of knowledge:

Then we work a lot with syllables, when you stand there and write in the writing workshop. We have practiced all the letters, how to write them, and I show on the board and then they get to practice. We have work sheets with both large and small letters. You write and see you can listen for letter sounds. //Word to picture. For every word, everything I draw, I can write something. I can write about the cupboard. The writing method is intended to get things started quickly and write about the tiniest detail. It need not be anything important. In this way I think you learn to read by writing a great deal. (LD)

\section{Teachers support strategies}

The analysis shows that teachers use various scaffolding to support and guide children in their own writing. One method is to support and guide the child by asking them questions that challenge their writing attempts: "Write about a dream you had. What did your monster look like? What was it called?" (LF). Teachers who actively participate in a child's emergent writing by asking questions are able to contribute to the child's interest in writing: "And you write about what you've drawn? So, I think that we've captured their interest in writing. At first, we see some who say: I don't want to!" (LE).

Another method of supporting and guiding children is to ask them to copy words written down by the teacher, or to try to imitate the teacher's writing. Children's ability to copy words is dependent on their level of knowledge and need for support: "We can then write first on a piece of paper; some want to, some write after, some already can. It's Lego, TV, Barbie. That's what they've written themselves." (LF).

The analysis shows that digital tools are used to support writing. One teacher allows children to use computers as writing tools in order to increase motivation and interest in writing:

It seemed to me that they had no joy in writing with a pen. They can form and write with the pen. But then it's, I've written two lines now. That will do! I've written my story and drawn an accompanying picture, but when I brought out the computers, they were asking: "Can we write tomorrow as well?". Now there's an interest in continuing. I want to continue my story. (LJ)

Another teacher describes her strategy to encourage children to write captions for pictures they have drawn, by asking them questions about their drawings. By allowing children to interact together in various social and educational contexts, they can also inspire one another to write: "Then they draw, one can say! But their friends see this and begin themselves. Then when we have a free period, many choose to sit with paper and pen and draw." (LE). 


\section{Joint writing}

The analysis shows that the work of teachers during group writing activities is characterised by modelling, for example, when the class have circle time and work thematically in the fields of nature, technology and society. The thoughts and experiences of children are also the point of departure when teachers model group writing.

It is very common to model group writing when its circle time; for example, this may involve the teacher writing that day's timetable on the whiteboard. According to teachers, modelling how the spoken word can be written down promotes the communicative function of writing, as well as letter recognition: "We have circle time each day where we write the date, then we might write something about the day, or write Monday; which letters are included? What letter is this?" (LL).

One didactic strategy for modelling Joint writing is when the teacher writes words associated with the current field of study on the board. On these occasions, children are challenged to make their own writing attempts, for example when writing in their own exercise books:

We also have a book linked to our science and social sciences work. There they can write down certain things depending on the subject we are studying. I have recently been working on the field of emergency services, ambulance and police. Then everyone is asked to write down certain words and if anyone wants to write more, then they can do so. (LI)

The thoughts and experiences of children can also be the point of departure when teachers model group writing. By finding out what children understand about a given subject and writing down their thoughts and words in the form of a mind map, the teacher can model how spoken words can be written down:

Whenever we begin a theme. When we started with anatomy in November. Now we are going to look at the body. What do you think about when we say 'body'? They say this; they say 'ears'. It's a bit like a mind map. (LK)

In the following example, teachers express how a common experience is used as the point of departure for group writing; the teacher models and demonstrates how a narrative is constructed by asking the children questions and, together with them, writes down a story: "Do we have a problem? How can we solve it? Let's go through it and write together. They tell me what to write. How does a story end?" (LC).

\section{Teachers'support strategies}

The analysis shows that teachers use various forms of scaffolding to support and guide children in Joint writing. For example, in the classroom, group writing exercises on the whiteboard may be reinforced image support to written word. One teacher describes how image support is initially used as scaffolding but that over time it becomes unnecessary:

We write down the daily timetable. Previously, we have used image support for example a picture and the word 'break time'. We have recently taken away the image 


\section{S. Andersson, G. Sandberg $\mathcal{E}$ A. Garpelin}

support and simply write instead. Because they are now familiar with the routine, everyone knows and we have no one who is particularly dependent on image support, so now we can write instead. (LL)

Another support strategy is for teachers to use artefacts in conversation with children. By adapting the lesson to the child's zone of proximal development and using guided discussion, the teacher is able to develop the child's knowledge of written language through phonemic analysis:

We sit with them and try to help them sound out words. How does the beginning sound? Do you hear $(\mathrm{mmm})$. Do you know what that letter looks like? And we also have small cards with the letters of the alphabet to which they can point. I have one who can clearly hear the sound of the letters, he knows exactly which letter sound it is but doesn't know what the letter looks like. So, he was able to make the sound and I could then say yes, and this is what the letter looks like. (LL)

The analysis of group writing and themed work also shows another form of scaffolding offered to pupils by teachers, when teachers write words on the board for children to copy when they are unable to write them themselves. Prewritten examples of words from which the children can copy are also used as scaffolding:

I have recently been working on the field of emergency services, ambulance and police. Then everyone is asked to write down certain words and if anyone wants to write more, then they can do so. And I either write on the board so that everyone can see, or I hand out small notes that they can copy from, or they can ask a friend. (LI)

This quote demonstrates that it is not only adults that provide support. More competent children can also be a source of support.

\section{Discussion}

The purpose is to deepen knowledge of how teachers in Swedish preschool classes describe their work to promote children's early writing. The preschool class has been criticized for not making the intended transition clear enough to children and impacting negatively on their reading and writing skills (Sandberg et al., 2015). Swedish studies have shown that preschool class teachers display an ambivalent attitude to the importance of developing children's early writing (Fast, 2007; Sandberg, 2012). The current study align with the referred studies, showing same kind of ambivalent attitude to working with writing activities. An additional result in this study stresses teachers' different approaches to teaching concerning writing.

The result shows that preschool class teachers express how they work to promote both individual and group writing. It reveals two different approaches regarding guiding children to develop their writing skills. First approach emphasises on working to develop creative and functional writing based on the child's own interests, life experiences and level of knowledge. The second approach is primarily characterised by working on technical abilities; forming letters of the alphabet and developing the child's phonological awareness. It was also found that there are teachers who use both approaches in their teaching. 
Regarding the Children's individual writing, the study reveals various examples of how teachers develop creative and functional writing based on the child's own interests, life experiences and level of knowledge during day-to-day teaching activities. One teacher models writing using the Writing Workshop method, with the intention of getting writing started at an early stage. Certain researchers advocate this method because some children learn to read by first writing (Chomsky, 1991; Ehri \& Wilce, 1987). Studies have shown that the method can be successful for children who require additional support and structured teaching (Behymer, 2003; Dennis \& Votteler, 2013; Jasmine \& Weiner, 2007). The study offers examples during day-to-day teaching activities of how children are stimulated to write based on their life experiences and interests in their Monday Book or when they evaluate the school week in their Calendar. Other studies have shown that when children are allowed to write from their own life experiences they are more motivated to write and to develop their imaginations and language skills (Behymer, 2003; Dennis \& Votteler, 2013; Eriksen Hagtvet, 1990; Jasmine \& Weiner, 2007). One didactic strategy revealed in the study is when teachers encourage children to draw pictures and add written words or captions based on their own level of knowledge. Researchers have shown that children who are allowed to draw pictures, invented spelling and/or write letters of the alphabet develop awareness of the communicative function of words, something that can positively affect their reading development (Barton, 2007; Chomsky, 1991; Clay, 1991; Gerde et al., 2015; Hofslundsengen et al., 2016).

The second approach is characterised by working on technical skills such as letter recognition and sound and phonological awareness. The study reveals how teachers primarily work with technical abilities. Researchers, including Eriksen Hagtvet (2006), have identified advantages to working didactically with technical abilities to increase children's motivation and interest in writing. Research results demonstrate the importance of phonological awareness to ongoing literacy development (Hagtvet, 1997; Lundberg, Frost \& Petersen, 1988). Also the importance to work in a structured way to develop phonological awareness in children at risk of having future reading and writing difficulties is stressed (Spear-Swerling, 2015).

The teachers engaged in this study place an emphasis on either creative and functional writing or technical abilities, but it appears from the analysis that there are teachers who use both approaches in their teaching; they work with both children's technical skills and with developing their own writing. Conversely, some researchers, including Hagtvet (2006), have demonstrated that it is necessary to base teaching on the fact that writing consist of a number of variables (writing $=$ encoding $\times$ conveying a message) and have highlighted the importance of balanced instructions that recognises these variables, i.e. using several of the above mentioned approaches. Swedish studies have shown that preschool class teachers display an ambivalent attitude to the importance of developing children's early writing (Fast, 2007; Sandberg, 2012). Alatalo et al., (2017) mention the possible connection between this attitude and the fact that preschool class teachers lack competence in the field of literacy development. According to Hermansson (2013), teachers in preschool classes have an important 


\section{S. Andersson, G. Sandberg $\mathcal{E}$ A. Garpelin}

role in guiding children and developing their writing through meaningful, text-creating activities.

With regard to foint writing day-to-day teaching activities, the study reveals that, among other things, teachers model writing when the class have circle time and during theme work. Other studies show that children's writing skills develop in a social context in which adults model writing and use written language in a context that is meaningful to children (Dennis \& Votteler, 2013; Gerde et al., 2012; Wasik \& Hindman, 2011). Other didactic strategies include when teachers in the study use the thoughts and experiences of children as a start for Joint writing day-to-day activities in order to increase awareness of the difference between spoken and written language. Other researchers have demonstrated the importance of adults, in their interactions with children, taking the child's thoughts as a starting point in order to make them aware of the difference between spoken and written language and the communicative function of the latter (Barton, 2007; Eriksen Hagtvet, 1990; Vygotsky, 1978).

With regard to teachers' support strategies, the study reveals how teachers offer support and stimulate children to make their own attempts at writing. Teachers offer both high-level and low-level support to children in their writing process. An example of high-level support is when the teacher writes words together with the child/ children and highlights the connection between the sound and the letter. Other studies confirm the importance of working with phonemic analysis and the positive effect this has on children's literacy development (Hofslundsengen el al., 2016). The study offers examples of high-level support for group writing activities, with a teacher using the Writing Workshop method to model narrative construction. Another teacher begins with a common experience to model how a narrative is constructed in dialogue with a class of children. Bingham et al., (2017) show how teachers primarily use low-level support and seldom model narrative construction. A common form of low-level support for Children's individual writing is when teachers allow a child to copy words they are unable to write themselves, something also demonstrated in the current study. It has however been shown that copying has a motivational effect and plays an important role in the child's language development linked to their zone of proximal development (Eriksen Hagtvet, 1990; Vygotsky, 1978; Wood, Bruner \& Ross, 1976). Some children need low-level support such as copying prewritten notes to motivate them to explore written language. Other children need high-level support based on their own zone of proximal level development to develop writing. There is no evidence that any level of support is preferred. Children are different and need different support depending on the level of knowledge.

The study reveals how different artefacts - such as visual timetable, drawings, exercise books, word written on the Whiteboard, prewritten notes or digital tools function as scaffolding for the child's writing process. Gerde et al., (2016) emphasise that the written word in the classroom environment is a useful tool for promoting children's writing. Previous studies have shown that the use of digital tools for writing is motivational and develops children's writing skills (Hultin \& Westin, 2013; Gerde 
et al., 2012), something that is also confirmed by a teacher in the current study. On the other hand, some studies have demonstrated that digital writing tools may hamper children's functional and creative writing (Skantz Åberg et al., 2014). Bingham et al., (2017) emphasise that a rich learning environment with access to various artefacts is not always sufficient for children to acquire written language skills. When the teacher actively uses both this rich learning environment and high-level support strategies, the children's writing will develop.

Studies have shown that teacher competency is important to prevent children from falling into reading and writing difficulties later in the education system. Studies have also shown that teachers who acquire increased competency in reading and writing theories can better provide children with adequate support (Alatalo et al., 2017). Making the preschool class compulsory and introducing separate text sections, with clearer teaching assignments into the preschool class curriculum may create better conditions for all children to gain an equivalent education. Government initiatives to increase teacher knowledge in reading and writing development have also begun to raise teachers' competency about theories of reading and writing development (Department of Education, 2015).

\section{Limitations}

This is a small-scale study and the result cannot be generalized. The twelve teachers who have participated in the study may be considered a narrow selection, given that such a large number of teachers declined to participate. The fact that the participants' interest was weak, twelve out of 185 were positive to participate, raised questions whether there was a lack of competence or uncertainty concerning teaching writing. Among those not participating, some explained that they had difficulties such as time shortage and too few planning hours. An important factor for understanding the result is that the study is based on teachers' statements about their own teaching and not studies of actual teaching.

\section{Conclusions}

This study constitutes a contribution to the discussion and questions regarding writing activities in preschool classes that lay the foundations for children's ongoing literacy. Phonological awareness and letter recognition are essential skills for learning to read and write. The current study shows that two different approaches are applied to children's individual writing, and that it is common to concentrate on developing children's technical abilities in reading and writing. Some teachers seem not to know how to guide children and developing their writing through various text-creating activities. In all likelihood, this lack of awareness can be explained by their lack of knowledge regarding how literacy develops. The study offers examples of various didactic strategies and artefacts used in the learning environment to develop 


\section{S. Andersson, G. Sandberg \& A. Garpelin}

children's writing, which may contribute to the discussion of how formalised and structured teaching needs to be. This study also offers an opportunity for teachers to reflect on the support strategies they offer and the levels of support required to meet different children's needs. In addition, reflect on what different ways teachers can promote children's early writing as writing, consists of several components, coding and conveying a message. The findings cannot be generalised to be valid for researchers in preschool class in general. Still there are some important findings that have implications for practitioners, politicians and researchers, concerning how to create pedagogical settings that provide optimal conditions for all children's writing development.

\section{Author biography}

Susanna Andersson is lecture in education and special needs education and $\mathrm{PhD}$ student at Department of Special Needs Education, Mälardalen University, Sweden. Her research interest focuses on early writing development in early childhood education.

Gunilla Sandberg is professor in education and special needs education at the Department of Special Needs Education, Mälardalen University, Sweden. Her research interest focuses on pedagogical transitions and reading and writing development.

Anders Garpelin is senior professor in education and special needs education at the Department of Special Needs Education, Mälardalens University, Sweden. His research interest focuses on pedagogical transitions and rites of passage.

\section{References}

Ahmad, S. T., \& Lombardino, L. J. (2000). Invented Spelling: An Assessment and Intervention Protocol for Kindergarten Children. Communication Disorders Quarterly, 22(1), 19-28.

Alatalo, T., Meier, J., \& Frank, E. (2017). Information Sharing on Children's Literacy Learning in the Transition From Swedish Preschool to School. Fournal of Research in Childhood Education, 31(2), 240-254.

Barton, D. (2007). Literacy an Introduction to the Ecology of Written Language. London: Blackwell Publishing.

Baker, L., Sher, D., \& Mackler, K. (1997). Home and Family Influences on Motivations for Reading. Educational Psychologist, 32(2), 69-82.

Behymer, A. (2003). Kindergarten Writing Workshop. Reading Teacher, 57(1), 85-88.

Bingham, G. E., Quinn, M. F., \& Gerde, H. K. (2017). Examining early childhood teacher's writing practices: Associations between pedagogical supports and children's writing skills. Early Childhood Research Quarterly, 39, 35-46.

Braun, V., \& Clark, V. (2006). Using thematic analysis in psychology. Qualitative Research in Psychology, 3(2), $77-101$.

Chomsky, C. (1991). Write first, read later. Childhood Education, 47, 296-300.

Clay, M. M. (1991). Becoming literate:The construction of inner control. Auckland: Heinemann Educational Books.

CODEX. (2019, 29. January) Regler och riktlinjer för forskning [Rules and guidelines for research]. Retrieved from http://www.codex.vr.se/index.shtml.

Dennis, L. R., \& Votteler, N. K. (2013). Preschool Teachers and Children's Emergent Writing Supporting Diverse Learners. Early Childhood Education fournal, 41, 439-446.

Denzin, N. (1996). Interpretative Ethnography. Newbury Park, CA: Sage. 


\section{To teach writing: Teachers'perspectives on how to promote children's writing}

Department of Education (2015). Mer tid för kunskap- förskoleklass förlängd skolplikt och lovskola. [More time for knowledge - preschool class, extended compulsory schooling and holiday school]. Stockholm: Utbildningsdepartementet.

Ehri, L. C., \&Wilce, L. S. (1987). Does Learning to Spell Help Beginners Learn to ReadWords? Reading Research Quarterly, 22(1), 47-65.

Erickson, E. H. (1986). Qualitative Methods in Research on Teaching. In M. C. Wittrock (Ed.), Handbook of Research and Teaching, (p. 119-161). New York. Macmillan Publishing Company.

Eriksen Hagtvet, B. (1990). Skriftspråksutveckling genom lek. [Written language development through play]. Stockholm: Natur och Kultur.

Fast, C. (2007). Sju barn lär sig läsa och skriva. Familjeliv och populärkultur $i$ möte med förskola och skola. [Seven children learn to read and write. Family life and popular culture in contact with preschool and school]. Uppsala: Acta Universitatis.

Forsey, M. (2012). Interviewing individuals. In S. Delamont (Ed.), Handbook of Qualitative Research in Education, (p. 364-376). Cheltenham: Edward Elgar Publishing Limited.

Gerde, H. K., Bingham, G. E., \& Pendergast, M. I. (2015). Reliability and Validity of the Writing Resources and Interaction in Teaching Environment (WRITE) for preschool classrooms. Early Childhood Research Quarterly, 31, 34-46.

Gerde, H. K., Bingham, G. E., \& Wasik, B. A. (2012). Writing in Early Childhood Classrooms: Guidance for Best Practices. Early Childhood Educational fournal, 40(6), 351-359.

Gerde, H. K., Goetsch, M. E., \& Bingham. G. E. (2016). Using Print in the Environment to Promote Early Writing. The Reading Teacher, 70(3), 283-293.

Hagtvet, B. E. (1997). Phonological and Linguistic-Cognitive Precursors of Reading Abilities. Dyslexia. An International fournal of Research and Practice, 3(3), 163-177.

Hagtvet, B. E. (2006). När riskbarn möter klassrumspraxis [When risk children meet classroom practice]. I L. Bjar, \& A. Frylmark (Red.), Barn läser och skriver [Children reading and writing], (s. 169-192). Lund: Studentlitteratur.

Hagtvet, B. E., Dalbye, M., Grindheim. E., Lillestølen. R., \& Palsdottir, H. (1988). Lek med språket [Play with the language]. Rapport fra et skriftspråkstimulerende tilbud for seksåringar [Report from a writing language stimulating offer for six-year-olds]. Oslo: Statens spesiallærerhögskole.

Hermansson, C. (2013). Nomadic Writing: Exploring Processes of Writing in Early Childhood Education. Karlstad: Karlstad Universitatis Studies 17.

Hofslundsengen, H., Eriksen Hagtvet, B., \& Gustafsson, J. E. (2016). Immediate and delayed effects of invented writing in preschool. Reading and Writing, 29, 1473-1495.

Hultin, E., \& Westman, M. (2013). Early Literacy Practices Go Digital. Literacy Information and Computer Education fournal, 4(2), 1096-1104.

Jasmine, J., \& Weiner, W. (2007). The Effects of Writing Workshop on Abilities of First Grade Students to Become Confident and Independent Writers. Early Childhood Education fournal, 35(2), 131-139.

Kvale, S., \& Brinkmann, S. (2014). Den kvalitativa forskningsintervjun. [The qualitative research interview]. Lund: Studentlitteratur.

Lundberg, I., Frost, J., \& Petersen, O. P. (1988). Effects of an Extensive Program for Stimulating Phonological Awareness in Preschool Children. Reading Research Quarterly, 23(3), 263-284.

Ouellette, G., \& Sénéchal, M. (2008). Pathway to Literacy: A Study of Invented Spelling and Its Role in Learning to Read. Child Development, 79(4), 899-913.

Sandberg, G. (2012). På väg in i skolan om villkor för olika barns delaktighet och skriftspråkslärande. [Towards school in terms of conditions for the participation of different children and written language learning]. Uppsala: Acta Universitatis.

Sandberg, G., Hellblom-Thibblin, T., \& Garpelin, A. (2015). Teacher's perspective on how to promote children's learning in reading and writing. European fournal of Special Needs Education, 30(4), 505-517.

Skantz Åberg, E., Lantz-Andersson, A., \& Pramling, N. (2014). Once upon a time there was a mouse: children's technology-mediated storytelling in preschool class. Early Child Development and Care, 184(11), 1583-1598.

Skoog, M. (2012). Skriftspråkande i förskoleklass och årskurs 1. [Written language in pre-school class and grade 1]. Örebro: Örebro Universitatis.

Spear-Swerling, L. (2015). Common Types of Reading Problems and How to Help Children Who Have Them. The reading teacher, 69(5), 513-522.

Swedish National Agency for Education. (2001). Integration förskoleklass, grundskola och fritidshem [Integration pre-school class, elementary school and leisure center]. Report no: 98:2144. Stockholm: Swedish National Agency for Education. 


\section{S. Andersson, G. Sandberg $\mathcal{E}$ A. Garpelin}

Swedish National Agency for Education. (2016a). Läroplan för grundskolan, förskoleklassen och fritidshemmet, Lgr 11. Rev. 2016 [Curriculum for elementary school, preschool class and leisure center, Lgr 11. Revised 2016]. Stockholm: Swedish National Agency for Education.

Swedish National Agency for Education. (2016b). Förskoleklassen - Ett kommentarmaterial till läroplanens tredje del [Preschool class - A commentary material for the third part of the curriculum]. Stockholm: Swedish National Agency for Education.

Swick, K. J. (2009). Promoting School and Life Success through Early Childhood Family Literacy. Early Childhood Educational fournal, 36(5), 403-406.

Säljö, R. (2010). Lärande och kulturella redskap Om lärprocesser och det kollektiva minnet [Learning and cultural tools About learning processes and collective memory]. Stockholm: Nordstedts.

Vygotsky, L. S. (1978). Mind in society The Development of Higher Psychological Processes. London: Harvard University Press.

Wasik, B. A., \& Hindman, A. H. (2011). The Morning Message in Early Childhood Classroom: Guidelines for Best Practices. Early Childhood Education Fournal, 39(3), 183-189.

Wood, D., Bruner, J. S., \& Ross, G. (1976). The Role of Tutoring in Problem-Solving. Fournal of Child Psychology and Psychiatry, 17(2), 89-100. 